\title{
Response of Wheat Cultivar under Conservation Agriculture
}

\author{
Sahely Kanthal ${ }^{1}$, Kingshuk Roy ${ }^{2}$, Shamik Dey ${ }^{3 *}$, Tufleuddin Biswas ${ }^{4}$, \\ M. Jaison ${ }^{5}$, Anitra Ali ${ }^{1}$, Tonmoy Paik ${ }^{1}$ and Aniket Baishya ${ }^{6}$ \\ ${ }^{1}$ Department of Agronomy, ${ }^{2}$ Department of Farm Machinery and Power, ${ }^{3}$ Department of \\ Agricultural Entomology, ${ }^{4}$ Department of Agricultural Statistics, ${ }^{5}$ Department of Agricultural \\ Chemistry and Soil Science, ${ }^{6}$ Department of Soil and Water Engineering, Bidhan Chandra \\ KrishiViswavidyalaya, Mohanpur, West Bengal, India \\ *Corresponding author
}

\section{Keywords}

Conservation

Agriculture,

Cultivars, Residues,

Tillage, Wheat,

Army worm

\section{Article Info}

Accepted:

17 November 2019

Available Online:

10 December 2019

\section{A B S T R A C T}

A field experiment was conducted in Balindi farm, Bidhan Chandra Krishi Viswavidyalaya, Mohanpur, West Bengal with five different wheat cultivars (viz., DBW39, DBW-107, HD-2967, CBW-38, DBW-187) which were grown under different regimes of conservation agriculture in a split-split plot experimental design. Main plot treatments include three different regimes of tillage intensity viz. Zero-tillage (ZT), Reduced tillage (RT) and Conventional tillage (CT). Subplot treatments are combinations of five level of different nutrient residues combination. Sub-sub plot treatments are five different types of wheat cultivars. Among the tillage systems, zero tillage showed the highest yield $(2,319 \mathrm{~kg}$ $\mathrm{ha}^{-1}$ ) compared to conventional tillage and no-tillage. Among the five nutrient residues combinations, $50 \%$ residue $+100 \%$ N.P.K gave significant yield and DBW-107 $(2,626.19$ $\mathrm{kg} \mathrm{ha}^{-1}$ ) performed well compared to other varieties. It was found that, among various combinations Zero tillage system with 50\% rice residues $+100 \%$ N.P.K with DBW-107 variety yield significantly compared to other combinations. Army worm (Mythimna separata) was the major problem during the wheat cultivation at its early growth stage mainly during tillering phase. It was effectively managed by the spot application of Regent (Fipronil) 5 SC @ $1 \mathrm{ml}$ per liter of water.

\section{Introduction}

Wheat plays a dominant role in global food security as it contributes almost $20 \%$ of the total dietary calories and proteins worldwide and almost 24\% in South Asia (Shiferaw et al., 2013). In India, wheat is grown on about 29 million ha and is an important crop for food security. As India accounts for $12 \%$ of global wheat production, any loss of 
production in the region will have major repercussions for global food security (FAO, 2013). Wheat productivity and total production in India increased tremendously with the advent of green revolution (GR). However, maintaining the gains of green revolution is increasingly a challenge with wheat yield in India having plateaued for last couple of years. Many factors such as declining soil fertility, degrading natural resources and increasing the cost of production inputs are responsible for the recent stagnation of wheat yield, further compounded by the effects of climate change and climatic variability. Climatic variability in terms of rainfall (drought, excess rains) and terminal heat (i.e. high temperature during grain filling stage) severely impact on wheat production in India. Therefore, farmers need to adjust the time of sowing as well as the wheat production system. Adverse impacts of climatic variability on crop productivity has become increasingly common in India. For instance, in 2004, due to high temperature wheat matured 10-20 days earlier than normal leading to a loss of more than 4 million $\mathrm{Mg}$ of wheat production (Samra and Singh, 2004). More recently in 2009-10, an abrupt increase in temperature during the grain filling stage of wheat was associated with an average yield loss of about 6\% in north-east India (Gupta et al., 2010). To ensure food security there is a need to focus on resource-efficient technologies that maximizes crop yield and increase adaptation to climatic variability.

In eastern Asian especially the country like India, the population of the country relive the pressure of food scarcity, low intensified rain and climate change due to the burning of previous surface residue is a severe issue which challenging conventional agriculture with conservation agricultural practice. This has led to strong advocacy by agricultural scientists for conversion to conservation agriculture (CA), featuring direct drilling of wheat into rice residues. Conservation agriculture-based wheat production system is based on the principle of minimum soil disturbance, permanent soil cover and crop diversification (intercropping and/ or rotation). Minimal soil disturbance long posed particular challenges to the adaptation and uptake of CA. This typically implies that a crop is established without any or with minimum prior tillage, a practice variously known as zero-tillage and reduced tillage.

In the rice-wheat system, Conservation agriculture offers a means of advancing the sowing date of wheat compared with the conventional tillage-based wheat production system due to the time saved with direct seeding. The Conservation agriculture-based wheat production system was introduced in India in 1990s as one of the resourceconserving technologies under the Rice-Wheat Consortium (Harrington and Erenstein, 2005).

Army worm (Mythimna separate), the major insect pest problem was encountered during this experimental period mainly in tillering phase of the crop. The damage symptoms was mainly manifested by the presence of cut ear head from the plant. This noxious pest was suppressed by the spot application of Regent (Fipronil 5SC), a good Phenyl-Pyrrazole insecticide @ $1 \mathrm{ml}$ per liter of water. Here spot application technique was taken into account to suppress the invading pest population, to avoid the chance of contact between insecticide and natural enemies and to reduce residual impact of the pesticide in the grain as well as environment.

Henceforth, this study was conducted to assess the differences of the yield of conservation agriculture to conventional agriculture. Yield of different wheat cultivars with different regimes of conservation agriculture was compared and conventional tillage was taken into this experiment in order to assess whether 
conservation agriculture have a yield benefit over conventional agriculture.

\section{Materials and Methods}

Land preparation in the conventional tillage system was done with disc plough as primary tillage followed by two pass disc harrow and one pass rotavator combined with planking as secondary tillage to have an excellent tilt and uniform seed-bed. The pathway of reduce tillage for wheat cultivation was done with disc plough as a primary tillage followed by two pass disc harrow as a secondary tillage. Seeding and fertilizer application was done mechanically by multi-crop seed cum fertilizer drill for conventional and reduce tillage. Zerotill ferti-seed drill was used for direct drilling of wheat and fertilizer into rice residues for zero tillage system.

Treated (Treated with fungicide) wheat seeds for five varieties were sown in the month of November in 1.08 ha of area having neutral soil $\mathrm{pH}$ (6.5-7.5) and each variety 0.189 ha with the seed rate of $100 \mathrm{~kg} \mathrm{ha}^{-1}$ and spacing of $25 \mathrm{~cm}$ between the rows and the recommended dose of 120:60:60 kg ha ${ }^{-1}$ of N.P.K. Half $\mathrm{N}$ and full $\mathrm{P}_{2} \mathrm{O}_{5}$ and $\mathrm{K}_{2} \mathrm{O}$ at basal and 2 top dressing each of 1/4th N. Irrigation was applied as per the requirement of the crop 2, 4 - D was used as a post emergence herbicide to control the sedge and grassy weeds. Wheat was harvested by self propelled vertical conveyor reaper and threshing was done with tractor powered axial flow thresher. The entire treatment details of our experiment was given below.

\section{Treatment details}

Season: Rabi, 2018-2019

Sowing date: $30^{\text {th }}$ November, 2018

Harvesting Date: $25^{\text {th }}$ March, 2019

\section{Name of the statistical design}

Split-Split

\section{Main plot}

\section{Tillage system}

Zero tillage (ZT)

Reduced tillage (RT)

Conventional tillage (CT)

\section{Subplot}

Nutrient residue combination

NR 1:0\% rice residues $+100 \%$ recommended dose of N.P.K

$\mathrm{NR}$ 2: $50 \%$ rice residues $+100 \%$ recommended dose of N.P.K

NR 3: $50 \%$ rice residues $+75 \%$ recommended dose of N.P.K

NR $4: 100 \%$ rice residues $+75 \%$ recommended dose of N.P.K

NR $5: 100 \%$ rice residues $+50 \%$ recommended dose of N.P.K

\section{Sub-sub plot}

Varieties

DBW-39

DBW-107

HD-2967

CBW-38

DBW-187 
The data has been analysed using Split-Split plot design (Gomez \& Gomez) through IBM*SPSS*Statistics software (Version 20). The analysed tool is general linear model, within that univariate option is considered. After that Syntax have been written for split split plot design. Then the result has obtained.

\section{Results and Discussion}

Tillage: Among the tillage system Zero tillage shows the highest yield $\left(2,319 \mathrm{~kg} \mathrm{ha}^{-1}\right)$ and conventional tillage shows the minimum yield $\left(1,591.52 \mathrm{~kg} \mathrm{ha}^{-1}\right)$

Nutrient residue combination: Among the five nutrient residues combinations, 50\% residue + $100 \%$ NPK shows the highest yield $(2,541.76$ $\mathrm{kg} \mathrm{ha}^{-1}$ ) and $100 \%$ residue $+50 \%$ NPK shows the minimum yield $\left(1,591.52 \mathrm{~kg} \mathrm{ha}^{-1}\right)$
Variety: among the five variety DBW-107 shows the highest yield $\left(2,626.19 \mathrm{~kg} \mathrm{ha}^{-1}\right)$ and DBW-39 shows the minimum yield (1,762.33 $\mathrm{kg} \mathrm{ha}^{-1}$ ).

From the Figure 1, it can be observed that wheat variety DBW-39 shows highest yield in reduced tillage $(2211 \mathrm{~kg} / \mathrm{ha})$ and lowest yield in conventional tillage $(1048 \mathrm{~kg} / \mathrm{ha})$. Wheat variety DBW-107 shows highest yield in Zero tillage $(3131 \mathrm{~kg} / \mathrm{ha})$ and lowest yield in conventional tillage $(1639 \mathrm{~kg} / \mathrm{ha})$. Wheat variety HD-2967 shows highest yield in zero tillage $(2051 \mathrm{~kg} / \mathrm{ha})$ and lowest yield in conventional tillage $(1349 \mathrm{~kg} / \mathrm{ha})$. Variety CBW-38 shows highest yield in reduced tillage $(2133 \mathrm{~kg} / \mathrm{ha})$ and lowest yield in conventional tillage $(1718 \mathrm{~kg} / \mathrm{ha})$.

Table.1 Yield of different varieties in different tillage with five nutrient-residue combination

\begin{tabular}{|c|c|}
\hline Tillage & Yield (Kg/ha) \\
\hline Zero tillage (ZT) & $\mathbf{2 , 3 1 9 . 0 0}$ \\
\hline Reduced tillage (RT) & $2,262.42$ \\
\hline Conventional tillage (CT) & $1,591.52$ \\
\hline CD $(\mathbf{0 . 0 5})$ & 82.284 \\
\hline SE $(\mathbf{m})$ & 21.075 \\
\hline Nutrient Residue Combination & Yield (Kg/ha) \\
\hline $\mathbf{0 \%}$ residue + 100\% N.P.K & $1,767.16$ \\
\hline $\mathbf{5 0 \%}$ residue + 100\% N.P.K & $\mathbf{2 , 5 4 1 . 7 6}$ \\
\hline $\mathbf{5 0 \%}$ residue + 75\% N.P.K & $2,293.84$ \\
\hline $\mathbf{1 0 0 \%}$ residue + 75\% N.P.K & $2,115.59$ \\
\hline $\mathbf{1 0 0 \%}$ residue + 50\% N.P.K & $1,569.88$ \\
\hline CD $(\mathbf{0 . 0 5})$ & 68.568 \\
\hline SE $(\mathbf{m})$ & 23.486 \\
\hline Variety & Yield (Kg/ha) \\
\hline DBW-39 & $1,762.33$ \\
\hline DBW-107 & $\mathbf{2 , 6 2 6 . 1 9}$ \\
\hline HD-2967 & $1,795.19$ \\
\hline CBW-38 & $1,983.64$ \\
\hline DBW-187 & $2,120.87$ \\
\hline CD $(\mathbf{0 . 0 5})$ & 69.426 \\
\hline SE (m) & 24.791 \\
\hline
\end{tabular}


Fig.1 Yield of different varieties under three tillage system

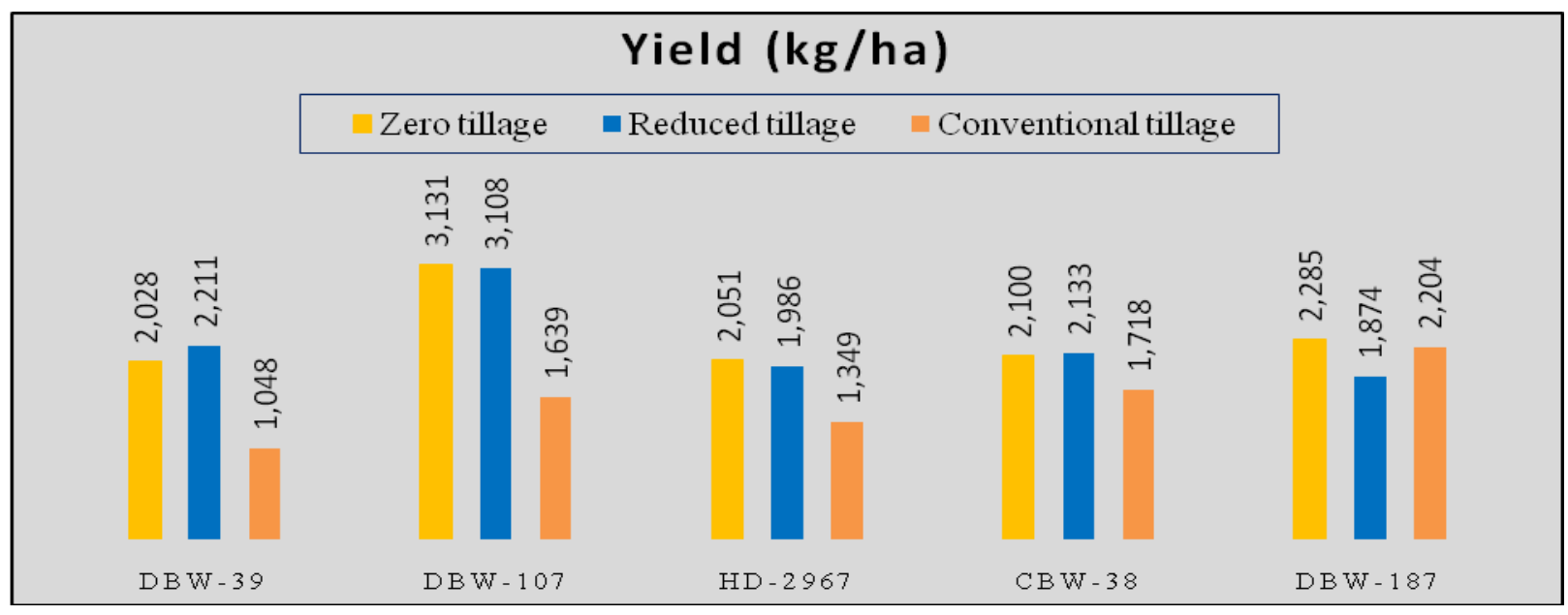

Fig.2 Yield of five varieties under different nutrient residue combinations

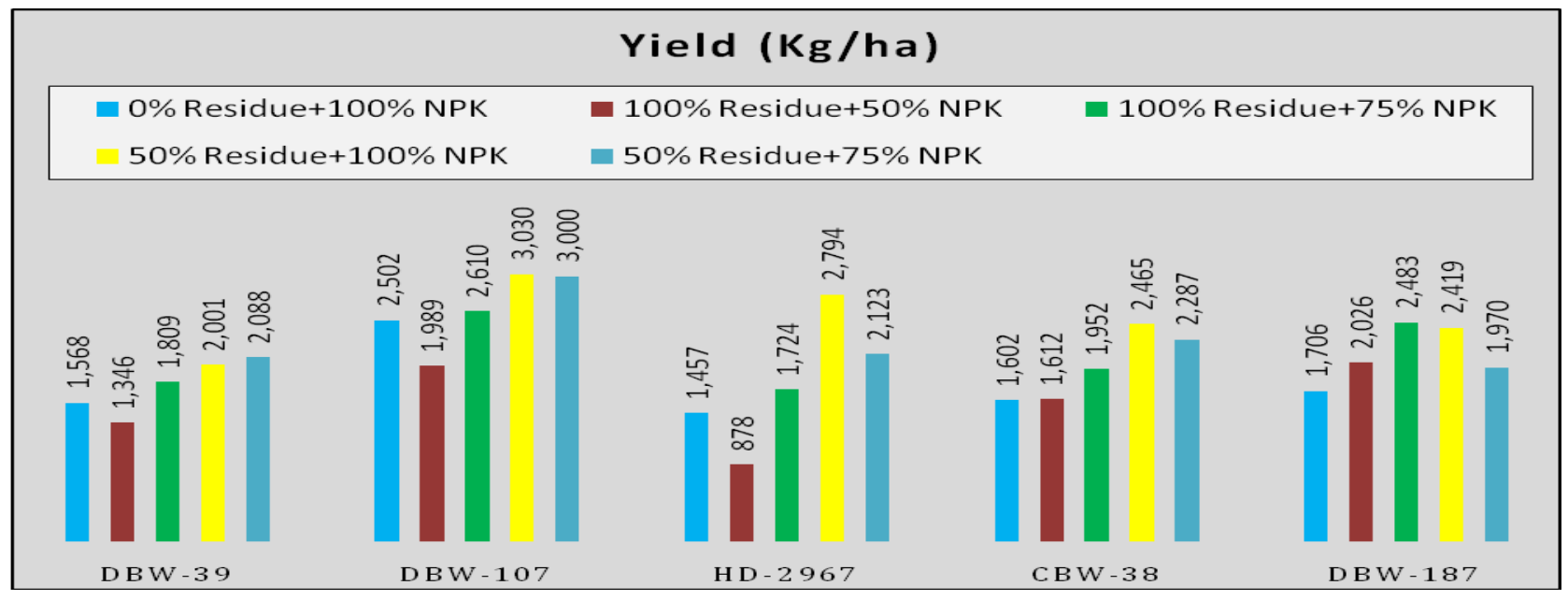

Fig.3 Effect of different nutrient residues and tillage system on wheat yield

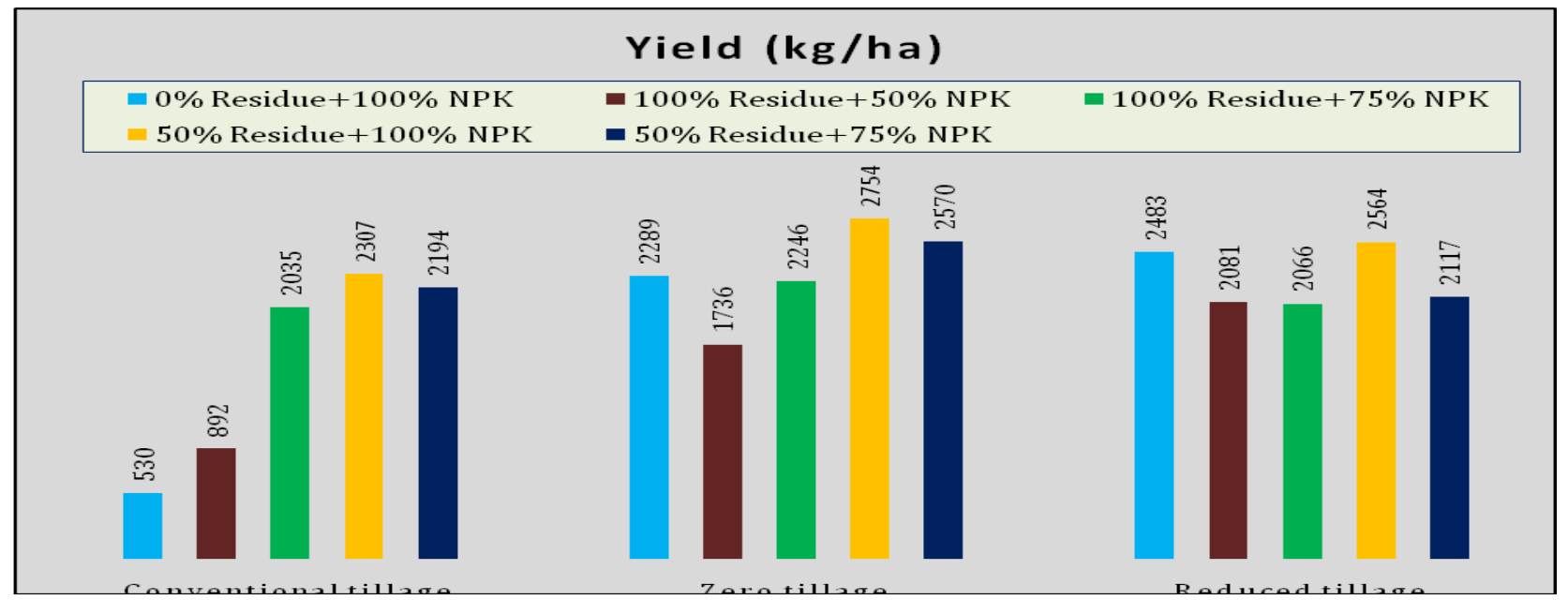


Variety DBW-187 shows highest yield in Zero tillage (2285 kg/ha) and lowest yield in reduced tillage $(1874 \mathrm{~kg} / \mathrm{ha})$. Mutonga et al., (2019) also reported more grain yield in zero till wheat than conventional agricultural practices by conserving more moisture. From the Figure 2, it can be observed that wheat variety DBW-39 shows highest yield in 50\% residue $+100 \%$ NPK $(2088 \mathrm{~kg} / \mathrm{ha})$ and lowest yield in $100 \%$ residue+50\% NPK(1346 $\mathrm{kg} / \mathrm{ha})$. Wheat variety DBW-107 shows highest yield in $50 \%$ residue $+100 \%$ NPK $(3030 \mathrm{~kg} / \mathrm{ha})$ and lowest yield in $100 \%$ residue $+50 \%$ NPK (1989 kg/ha). Variety HD-2967 shows highest yield in $50 \%$ residue $+100 \%$ NPK $(2794 \mathrm{~kg} / \mathrm{ha})$ and lowest yield in $100 \%$ residue $+50 \%$ NPK (878 kg/ha). Variety CBW-38 shows highest yield in $50 \%$ residue $+100 \%$ NPK $(2465 \mathrm{~kg} / \mathrm{ha})$ and lowest yield in 0\% residue $+100 \%$ NPK (1602 kg/ha). Thapa et al., (2019) also shows similar observations. Variety DBW-187 shows highest yield in $100 \%$ residue $+75 \%$ NPK $(2483 \mathrm{~kg} / \mathrm{ha})$ and lowest yield in $0 \%$ residue $+100 \%$ NPK (1706 kg/ha).Govaerts et al., (2005) also observed long term practices of zero tillage with residue retention resulted in higher yield than without residue retention.

Figure 3 shows that under conventional tillage $50 \%$ residue $+100 \%$ NPK $(2307 \mathrm{~kg} / \mathrm{ha})$ perform best and $0 \%$ residue $+100 \%$ NPK (892 $\mathrm{kg} / \mathrm{ha}$ ) shows lowest yield. Under zero tillage $50 \%$ residue $+100 \%$ NPK $(2754 \mathrm{~kg} / \mathrm{ha})$ shows the highest yield and $100 \%$ residue $+50 \%$ NPK (1736 kg/ha) shows lowest yield. Under reduced tillage $50 \%$ residue+100\% NPK $(2564 \mathrm{~kg} / \mathrm{ha})$ shows the highest yield and $100 \%$ residue $+75 \%$ NPK $(2066 \mathrm{~kg} / \mathrm{ha})$ shows lowest yield.

From the above results it can be documented that Zero tillage system with $50 \%$ rice residues and 100\% NPK with DBW-107 variety shows the maximum yield in wheat. This result may be due to the better resource utilization and addition of organic residues in the soil (Table 1). From the present study it can be clearly concluded that conservation agriculture practices does not reduce the grain yield of wheat. This study showed that Zero tillage system with $50 \%$ rice residues and $100 \%$ N.P.K may be the best conservation intervention to optimize yield in wheat. This study also shows that DBW- 107 perform better under conservation agriculture practices.

\section{Acknowledgement}

I express my deep sense of gratitude to Prof.Biswapati Mandal, Department of Agricultural Chemicals and Soil Science, Prof. Mahadev Paramanik, Dept. of Agronomy, Prof. Krishna Karmakar, Department of Agricultural Entomology, Prof. Subrata Karmakar, Department of Farm Machinery and Power Bidhan Chandra Krishi Viswavidyalaya for their invaluable guidance, technical support, constant encouragement, constructive comments and novel ideas throughout the period of the work.

\section{References}

FAO, (2013). Food and agricultural commodities production: countries by commodity [WWW Document].

Gomez, K., and Gomez, A. 1984. Statistical Procedures for Agricultural Research. Singapore: John Willey \& Sons, Inc.

Govaerts, B., Sayre, K.D. and Deckers, J. 2005. Stable high yields with zero tillage and permanent bed planting? Field crops research, 94(1): 33-42.

Gupta, R., Gopal, R., Jat, M.L., Jat, R.K., Sidhu, H.S., Minhas, P., Malik, R. 2010. Wheat productivity in IndoGangetic Plains of India during 2010: terminal heat effects and mitigation strategies. Conserv. Agric. 14: 1-3.

Harrington, L., and Erenstein, O. 2005. Conservation agriculture and resource 
conserving technologies - a global perspective. In: Abrol, I.P., Gupta, R.K., Malik, R.K. (Eds.), Conservation Agriculture - Satus and Prospects. Centre for Advancement of Sustainable Agriculture, NASC Complex, New Delhi, India, pp. 1-12. Mutonga, M.W., Kipkorir, E.C. and Ng'etich, W.K. 2019. Assessment of Effects of Zero and Conventional Tillage Practices on Soil Moisture and Wheat Grain Yield in Arid and Semi-Arid Land of Laikipia, Kenya. Water
Conservation Science and Engineering. 4(1): 43-52.

Samra, J.S., and Singh, G. 2004. Heat Wave of March 2004: Impact on Agriculture. Indian Council of Agricultural Research, New Delhi, India.

Shiferaw, B., Smale, M., Braun, H.-J., Duveiller, E., Reynolds, M., and Muricho, G. 2013. Crops that feed the world 10. Past successes and future challenges to the role played by wheat in global food security. Food Secur. 5: 291-317.

\section{How to cite this article:}

Sahely Kanthal, Kingshuk Roy, Shamik Dey, Tufleuddin Biswas, M. Jaison, Anitra Ali, Tonmoy Paik and Aniket Baishya. 2019. Response of Wheat Cultivar under Conservation Agriculture. Int.J.Curr.Microbiol.App.Sci. 8(12): 2419-2425. doi: https://doi.org/10.20546/ijcmas.2019.812.284 